\title{
INOVASI WEBSITE ALUMNI PENDIDIKAN TEKNIK INFORMATIKA (Studi Kasus di Jurusan PTI, FTK, Undiksha)
}

\author{
Oleh \\ I Made Putrama \\ Jurusan Pendidikan Teknik Informatika, FTK, UNDIKSHA \\ made.putrama@undiksha.ac.id
}

\begin{abstract}
ABSTRAK
Sistem Tracer Study yang dibuat untuk alumni PTI Undiksha adalah sebuah sistem berbasis web yang merupakan pengembangan sistem layanan yang dikhususkan untuk menggali informasi mengenai data lulusan baik yang baru menyelesaikan studi maupun yang telah bekerja setelah lulus dari Jurusan PTI Undiksha. Sistem Tracer Study penggalian data alumni ini dibuat sebagai pelengkap sistem informasi yang telah ada di PTI seperti halnya WANAPATI yang juga memuat ringkasan tentang profil Alumni. Website WANAPATI dibuat lebih dikhususkan sebagai penyedia layanan statistical mengenai lulusan sedangkan sistem Tracer Study ini dibutuhkan untuk kepentingan pembaharuan data alumni yang sewaktu-waktu dapat diakses oleh para alumni dari manapun mereka berada. Secara ringkas penelitian ini dilakukan untuk merancang pengembangan sistem Tracer Study yang dimaksud dengan menggunakan metode pengembangan (Research and Development) yang tahap perancangan sistemnya menggunakan metodologi Software Development Life Cycle (SDLC) dengan model Incremental. Dua metode verifikasi sistem standar yaituwhite-box dan black-box testing diterapkan sebagai bagian dari methodologi tersebut dilakukan dalam penelitian ini untuk memverifikasi keabsahan sistem sebelum dan sesudah pengembangan. Luaran dari penelitian ini berupa pembaharuan website PTI Undiksha dengan tambahan fitur Tracer Study yang telah diuji dan berfungsi dengan baik saat ini.
\end{abstract}

Kata-kata kunci-Tracer Study, Website Alumni, Statistik Alumni, Biodata Alumni, Alumni PTI Undiksha

\begin{abstract}
The Tracer Study is a part of an Information System evolution which was enhanced on top of the existing website of the Informatics Engineering Education of Faculty of Engineering in Ganesha University of Education (PTI Undiksha) for a purpose to facilitate the gathering of information related to alumni be it for the fresh graduates as well as the ones who have been working long time after their graduation. The tracer study feature was added along some improvement to the existing features and as a compliment to the other existing alumni website which is more focusing on the statistical summary of student information such as WANAPATI Undiksha. Unlike WANAPATI, this Tracer Study system was built to accommodate the student information profile update such that it will be accessible by the alumni anytime anywhere. The system was developed with the Research and Development $(R \& D)$ approach specifically following the Software Development Life Cycle (SDLC) methodology with Incremental model. Two standard system testing, whitebox and blackbox testing verification was conducted to validate the state of the system before and after the enhancement. The output of this research is the new improved system for the PTI Undiksha which is now up and running successfully.
\end{abstract}

Keywords - Tracer Study, Alumni Website, Alumni Statistical, Alumni Biodata, Alumni PTI Undiksha 


\section{PENDAHULUAN}

Sistem Informasi Alumni WANAPATI Universitas Pendidikan Ganesha adalah sebuah sistem informasi berbasis web yang digunakan untuk memberikan informasi terkait dengan para alumni dari Jurusan Pendidikan Teknik Informatika (PTI) Undiksha. Website WANAPATI bisa dikases oleh kalangan luar baik umum maupun internal yang utamanya adalah para lulusan, mahasiswa dan juga dosen/pegawai dari Jurusan tersebut.

Website WANAPATI pada dasarnya sudah berjalan dan sudah menampung data lulusan dari tahun 2007 namun masih dirasa minim informasi. Adapun informasi yang ada saat ini berupa biodata dan statistik alumni yang masih ditampilkan secara singkat dan juga belum terintegrasi dengan baik dengan perangkat mobile lain ataupun dengan website lain yang berkaitan yang saat ini dikelola PTI.

Namun beberapa fitur yang perlu diperbaharui diantaranya seperti (1)Informasi mengenai jurnal yang dikerjakan alumni yang dimuat di website lain yaitu JANAPATI (Jurnal Pendidikan Teknik Informatika), belum bisa ditelusuri secara langsung dari website WANAPATI ini(2) Website ini mestinya menjadi acuan yang memberikan referensi terbaru mengenai alumni itu sendiri, misalnya fitur untuk melakukan update secara langsung baik oleh alumni itu sendiri ataupun administrator WANAPATI, untuk menambahkan informasi tertentu yang sifatnya memang bisa diubah seperti data kontak, alamat terbaru dan khususnya informasi tempat kerja atau pekerjaan pertama yang sudah diperoleh alumni tersebut terhitung sejak dinyatakan lulus dari Undiksha. Informasi ini diharakan bisa digunakan lebih lanjut untuk keperluan pendataan tentang alumni bersangkutan dan juga dapat memberikan gambaran tentang seberapa baik daya serap lapangan kerja terhadap lulusan Undiksha khususnya lulusan dari Jurusan Pendidikan Teknik Informatika(3) Website lain yang dikelola PTI sepertiWeb Based Digital Library (DIGILIB) yang khususnya menampilkan informasi mengenai data skripsi yang telah dikerjakan oleh seorang mahasiswa juga semestinya bisa dihubungkan secara langsung dengan WANAPATI(4) Fitur yang dapat digunakan khususnya oleh para alumni untuk bisa memperbaharui informasi terkini terkait data dirinya masing-masing dan juga fasilitas untuk membantu kegiatan Temu Alumni semestinya juga ditambahkan(5) Fitur dimana seorang alumni memerlukan informasi untuk menelusuri biodata alumni lain dan fitur untuk saling bertukar informasi semestinya juga disediakan (6) Beberapa permasalahan tampilan yang masih perlu penyempurnaan juga menjadi bagian yang seharusnya menjadi perhatian saat pengembangan website WANAPATI ini dilakukan.

Atas dasar analisa dari latar belakang di atas, peneliti melakukan inovasi terhadap website WANAPATI dengan penambahan fitur yang difokuskan pada Tracer Studyonline

JPTK, UNDIKSHA, Vol. 13, No. 1, Januari 2016 : 35 - 49 
yang saat ini masih dilakukan secara manual. Fitur Tracer Study ini diharapkan mampu menunjang penggalian dan pembaharuan informasi profil alumni PTI Undikshauntuk digunakan sebagai acuan dalam kajian lain yang membutuhkan pengolahan data lulusan.Tracer Study merupakan studi penelusuran alumni untuk mengetahui kegiatan alumni setelah lulus dari perguruan tinggi, transisi yang mereka alami dari dunia pendidikan ke dunia kerja bagi yang sudah bekerja, pengalaman bekerja, perolehan kompetensi dan penggunaan kompetensi yang dibutuhkan di dunia kerja yang dikumpulkan dari para alumni dengan harapan dapat dipakai acuan pembenahan atau peningkatan kualitas lulusan di masa mendatang.

Sebelum fiturTracer Study ini ditambahkan ke dalam website WANAPATI, aktifitas ini dilakukan secara manual dengan menyebarkan angket ke beberapa lulusan yang mana pengerjaannya membutuhkan waktu yang tidak sedikit dan juga tidak efektif dan tidak efisien dari segi waktu. Karena angket harus dibawakan langsung ke alamat lulusan dimana dia berada atau bekerja dan respon yang diberikan juga tidak bisa dilihat secara langsung karena masih ada tahap verifikasi dan perhitungan manual yang perlu dilakukan.

Dengan inovasi penambahan fitur Tracer Study ini secara online ke dalam website WANAPATI, diharapkan pelaksanaan kegiatan pembaharuan informasi alumni ini dapat dilakukan sewaktu-waktu dengan cukup memberikan notifikasi kepada mereka secara serentak untuk mengisi survei secara online yang bisa diakses oleh mereka dari mana saja dan kapan saja.

\section{SISTEM INFORMASI}

Ada beberapa konsep tentang Sistem Informasi yang mendasari kajian dalam penelitian ini dimana pengembangan WANAPATI perlu dilakukan sehingga sistem tersebut dapat dibuat sesuai tujuannya dan dapat memberikan manfaat yang lebih besar dari sekedar menampilkan informasi tentang lulusan namun juga dapat meng-capture informasi terkini dari alumni PTI FTK Undiksha. Yang pertama, menurut pandangan yangdikemukakan R.Kelly (2014), Sistem Informasiadalah sistem yang berbasiskan komputer dimana sebagian ataupun seluruh pengerjaan tugas-tugasnya menggunakan teknologi komputer. Menurut O'Brien (2003), Sistem Informasi merupakan kombinasi yang teratur antara orang-orang, hardware, software, jaringan komunikasi, dan sumber daya data yang mengumpulkan, mengubah, dan menyebarkan informasi dalam sebuah organisasi. Adapula pandangan menurut definisi Azhar Susanto (2004:46), Sistem Informasi adalah sistem yang mengolah data yang memberikan arti dan manfaat.Serta 
menurut Jogianto (2005), Sistem Informasi nformasi adalah data yang diolah menjadi bentuk yang lebih bergunadan lebih berarti bagi yang menerimanya.

\section{WANAPATI}

WANAPATI merupakan sistem informasi yang dibangun khusus untuk alumni PTI FTK Undiksha. WANAPATI yang ada saat ini berupa website berbasiskan client-server yang dikelola oleh pihak Pusat Komputer Universitas Pendidikan Ganesha (PUSKOM) yang juga mengelola website lembaga dan website jurusan-jurusan lain baik dari Fakultas Teknik dan Kejuruan (FTK) Undiksha maupun dari fakultas-fakultas lainnya.

Informasi yang ada di WANAPATI saat ini masih sebatas informasi tentang lulusan yang dikelompokkan berdasarkan tahun lulus namun tidak ada informasi lain misalkan fasilitas forum untuk mahasiswa, fitur untuk menampilkan event alumni tertentu juga tidak tersedia. Menurut Azhar Susanto (2004:46) mendefinisikan informasi sebagai "informasi adalah hasil pengolahan data yang memberikan arti dan manfaat" sehingga WANAPATI perlu dikembangkan lagi sehingga akan lebih memberikan manfaat dan dapat digunakan alumni dimanapun berada untuk saling bertukar informasi. Website WANAPATI yang ada dapat dilihat seperti pada Gambar 1.

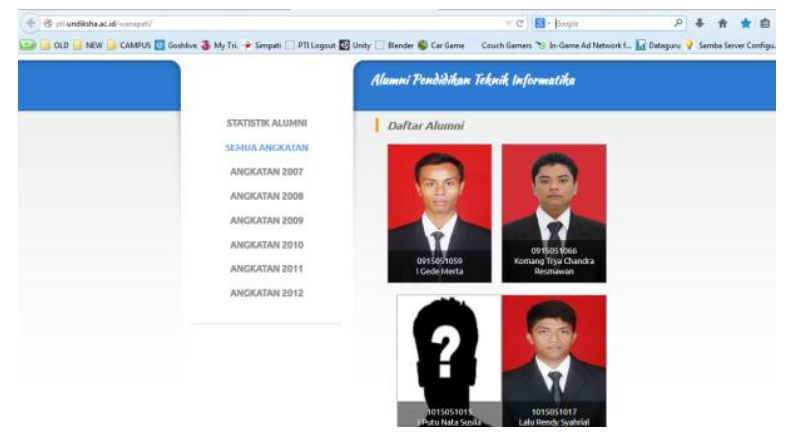

Gambar 1. Sistem Informasi Alumni Jurusan Pendidikan Teknik Informatika WANAPATI) Undiksha

Komputer yang bertindak sebagai Server ada di Pusat Komputer (PusKom) Undiksha dan yang bertindak sebagai Client adalah browser seperti Internet Explorer atau Mozila Firefox yang ada di komputer-komputer pengguna layanan. 


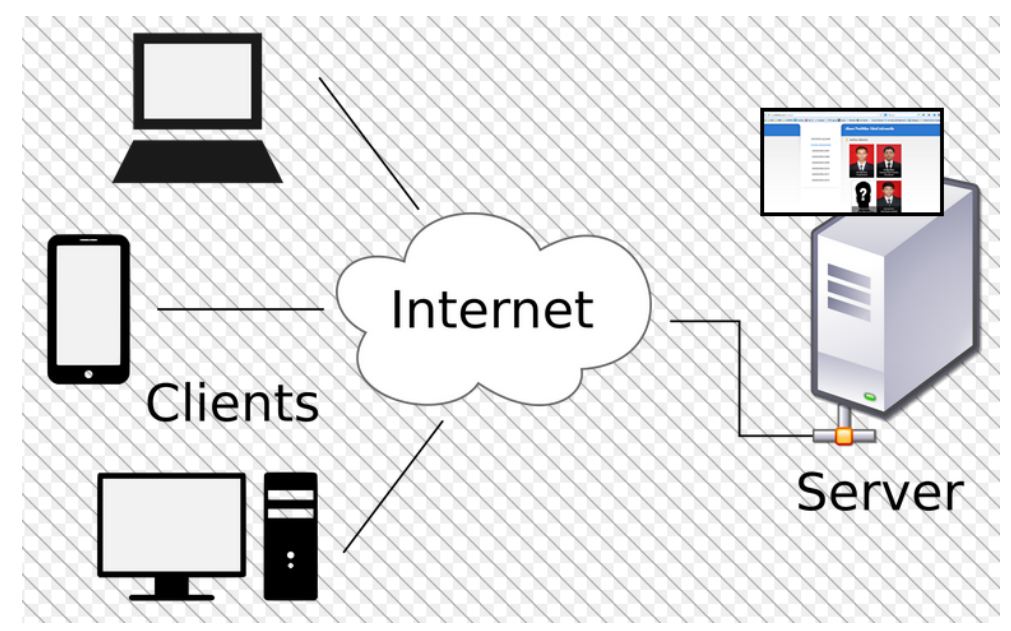

Gambar 1. Konfigurasi Client-Server

\section{METODE PENELITIAN}

Metodologi yang digunakan untuk mengembangkan perangkat lunak ini adalah SDLC (System Development Life Cycle).

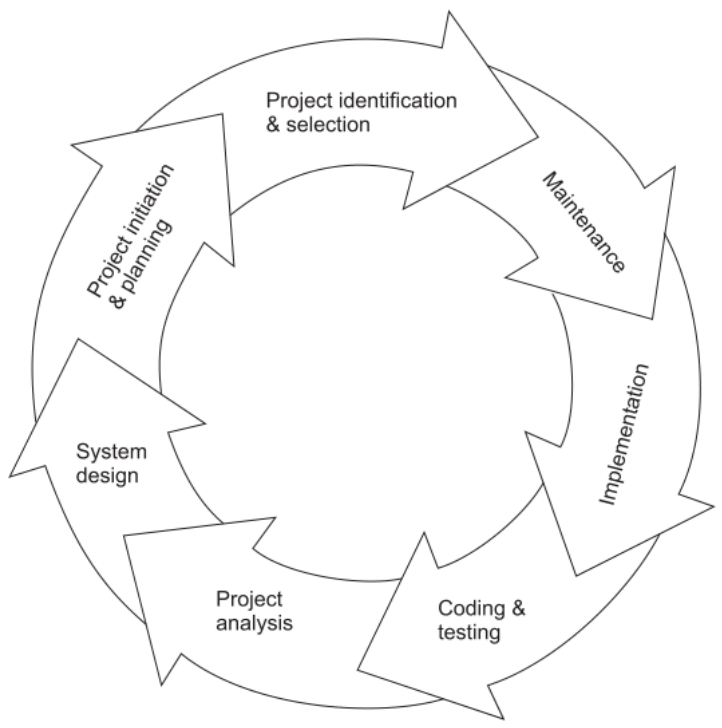

Gambar 3. System Development Life Cycle(Agarwal, 2010:32)

SDLC adalah proses pembuatan dan pengubahan sistem serta model dan metodologi yang digunakan untuk mengembangkan sistem-sistem tersebut. Dimana pola pengerjaannya mengikuti beberapa fase seperti: rencana (project initiation \&planning), analisis (project identification and selection/feasibility study, project analysis), desain (system design), implementasi (coding, testing, implementation), dan pengelolaan (maintenance). 
Secara spesifik pengembangan sistem ini dilakukan melalui tahapan SDLC dengan model Incremental (Iterative-enhancement Model) yang ditunjukkan dalam gambar 4 berikut ini.

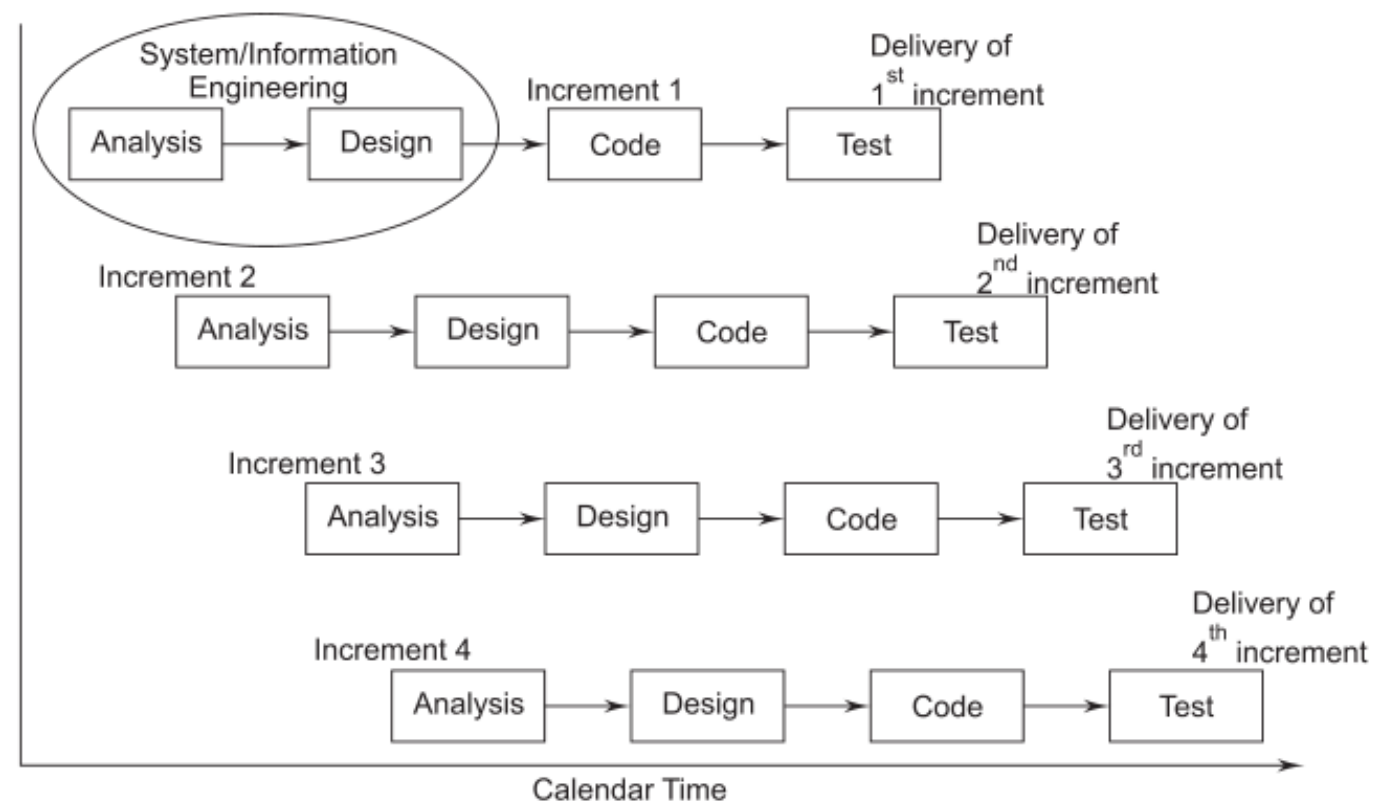

Gambar 4. Model Iterative-Enhancement(Agarwal, 2010:47)

Pada tahap Analisa Kebutuhan atau Requirement Analisis, dikemukakan hal-hal yang perlu dikembangkan terkait dengan fitur yang dibutuhkan dalam Tracer Study ini, diantaranya (1) Alumni dapat mengisi data diri dan informasi lain terkait status pekerjaannya (2) Pihak yang memakai jasa alumni seperti perusahaan tertentu dapat memberikan feedback terkait pemanfaatan kompetensi dalam kegiatan bisnis mereka yang berhubungan dengan keterampilan yang dimiliki alumni (3) Pihak lembaga Undiksha dapat melihat informasi hasil survey/Tracer Study dalam bentuk grafik statistik untuk mengetahui gambaran profil alumni secara khusus maupun secara keseluruhan hasil survey. 


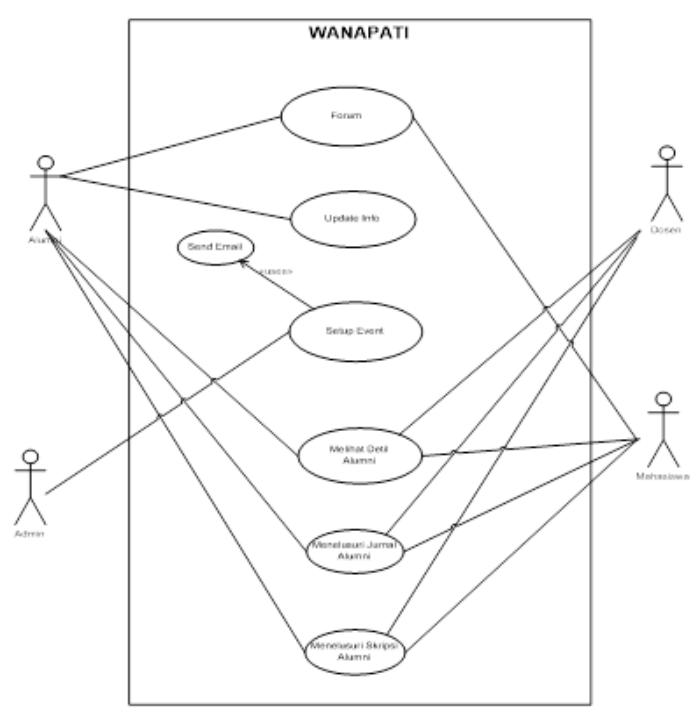

Gambar 5. Use Case Diagram

Tahapan Desain dan Pengembangan dilakukan dengan menggambarkan fitur ke dalam Use Case yang dapat dilihat dalam Gambar 5.

\section{HASIL DAN PEMBAHASAN}

Pada tahap implementasi, sistem Tracer Study dibuat dan divalidasi melalui tahapan pengujian Whitebox dan Blackbox testing yang dilakukan oleh pengmbang sendiri, dalam hal ini dibantu oleh teknisi dari Pusat Komputer (Puskom) Undiksha. Pemasangan dan pemeliharaan juga dilakukan oleh pihak Puskom sendiri.

Secara ringkas, arsitektur sistem yang dikembangkan dapat dirinci sebagai berikut (1) menggunakan tampilan User Interface berdasarkan teknologi Web 2.0, HTML5 responsive (2) berbasiskan pemrograman PHP dan database MySQL (3) terintegrasi dengan website PTI Undiksha yang lain di laman http://pti.undiksha.ac.id yang secara khusus berada pada sub-domain http://pti.undiksha.ac.id/tracer.

Fitur yang ada dalam Tracer Study ini diantaranya (1) Fitur untuk Alumni berisi fasilitas pemberian informasi biodata, tempat kerja, masa tunggu, gaji, cara mendapatkan info pekerjaan, saran yang dapat diberikan alumni terhadap sistem Tracer Study tersebut (2) Fitur untuk Stakeholders berisi fasilitas pemberian informasi disiplin kerja alumni dan kompetensi alumni(3) Fitur penampilan informasi survei secara stastistikal.

Aksesibilitasnya mencakup (1) diperuntukkan bagi lulusan PTI Undiksha (2) fitur keamanan/login (3) alumni angkatan $\geq 2010$, bisa langsung login menggunakan Username/Pass $\rightarrow$ NIM dan harus mengubah passwordnya setelahnya sebelum mengisi angket Tracer Study yang disediakan (4) alumni angkatan $\leq 2009$, mahasiswa harus 
mendaftarkan terlebih dahulu untuk kemudian Username/Password nya akan dikirimkan ke emailnya masing-masing (data di SIAK tidak lengkap -DOB, Tgl Angkatan, Tgl Kelulusan, dan seterusnya) (5) isian Tracer Study mengharuskan mahasiswa mengisi instrument/angket mengenai profile mereka khususnya tentang pekerjaannya saat ini.

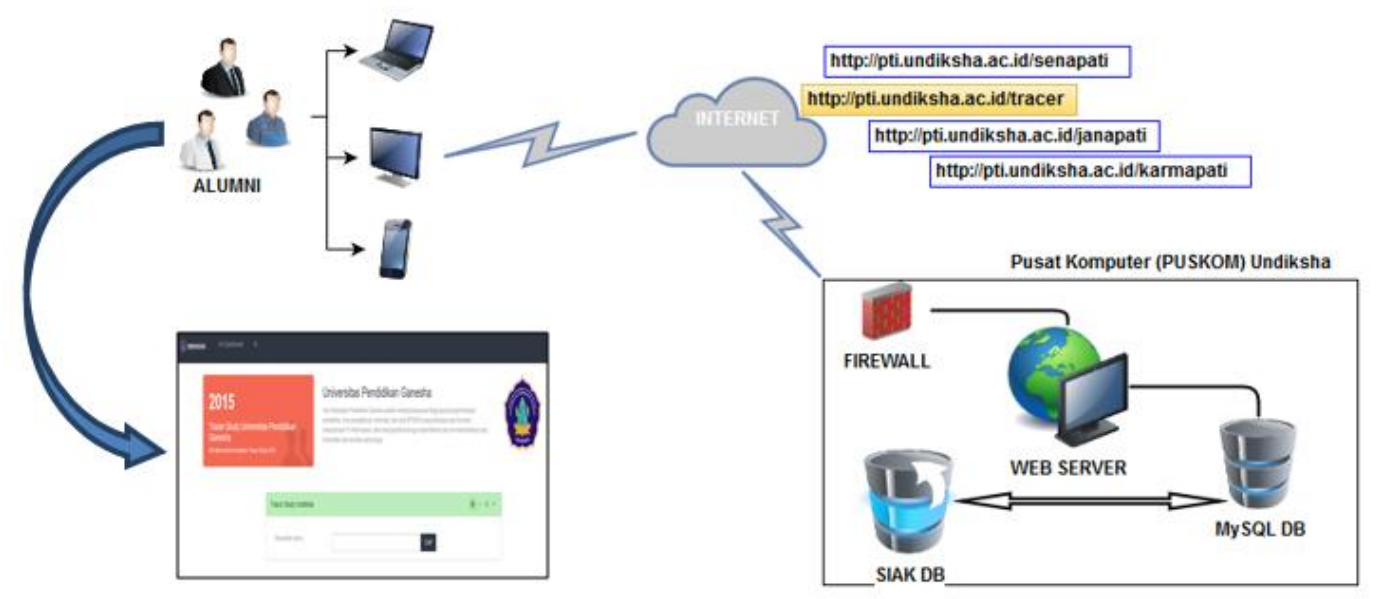

Gambar 6. Implementasi Arsitektur Sistem Tracer Study PTI undiksha

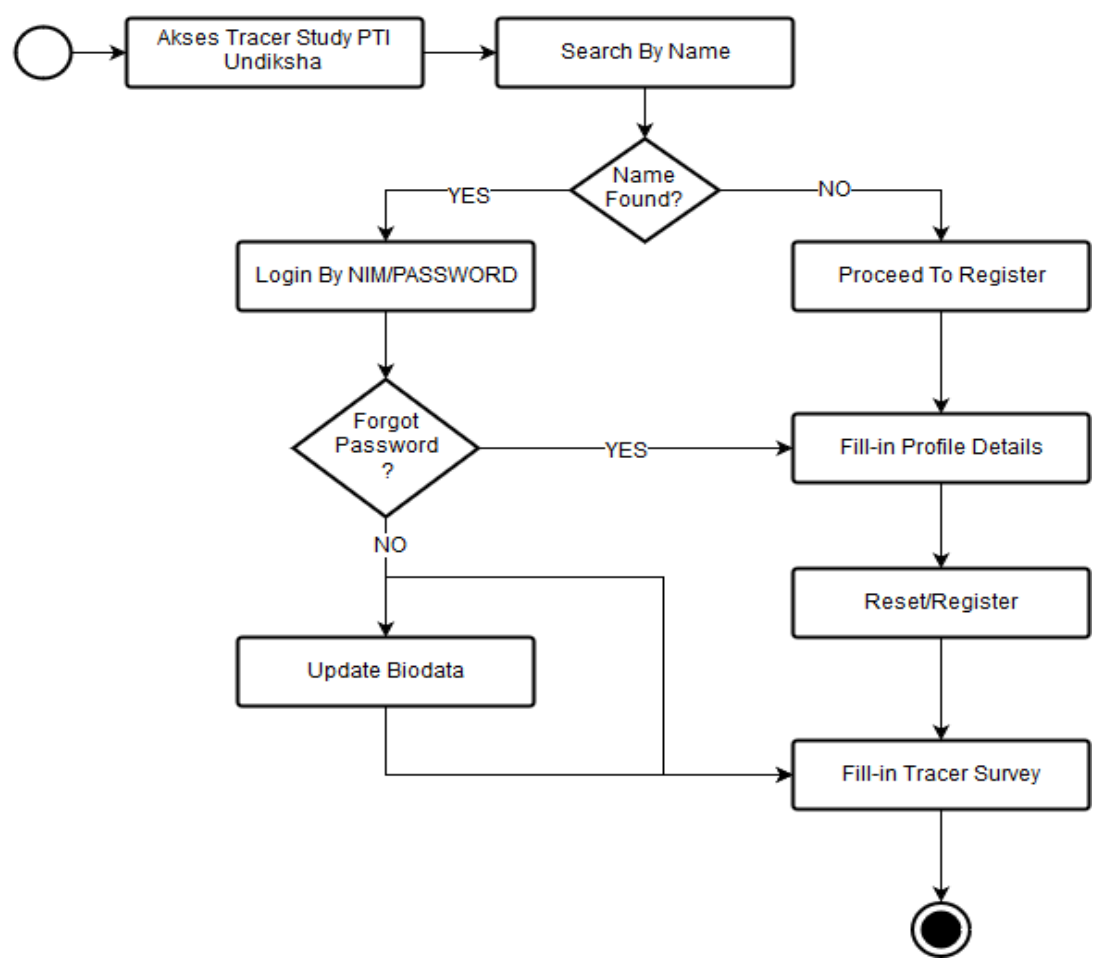

Gambar 7. Workflow Sistem Tracer Study 


\section{User Interface}

Hasil tampilan sistem Tracer Study PTI Undiksha yang telah diselesaikan dapat dilihat seperti pada Gambar 9 berikut ini.

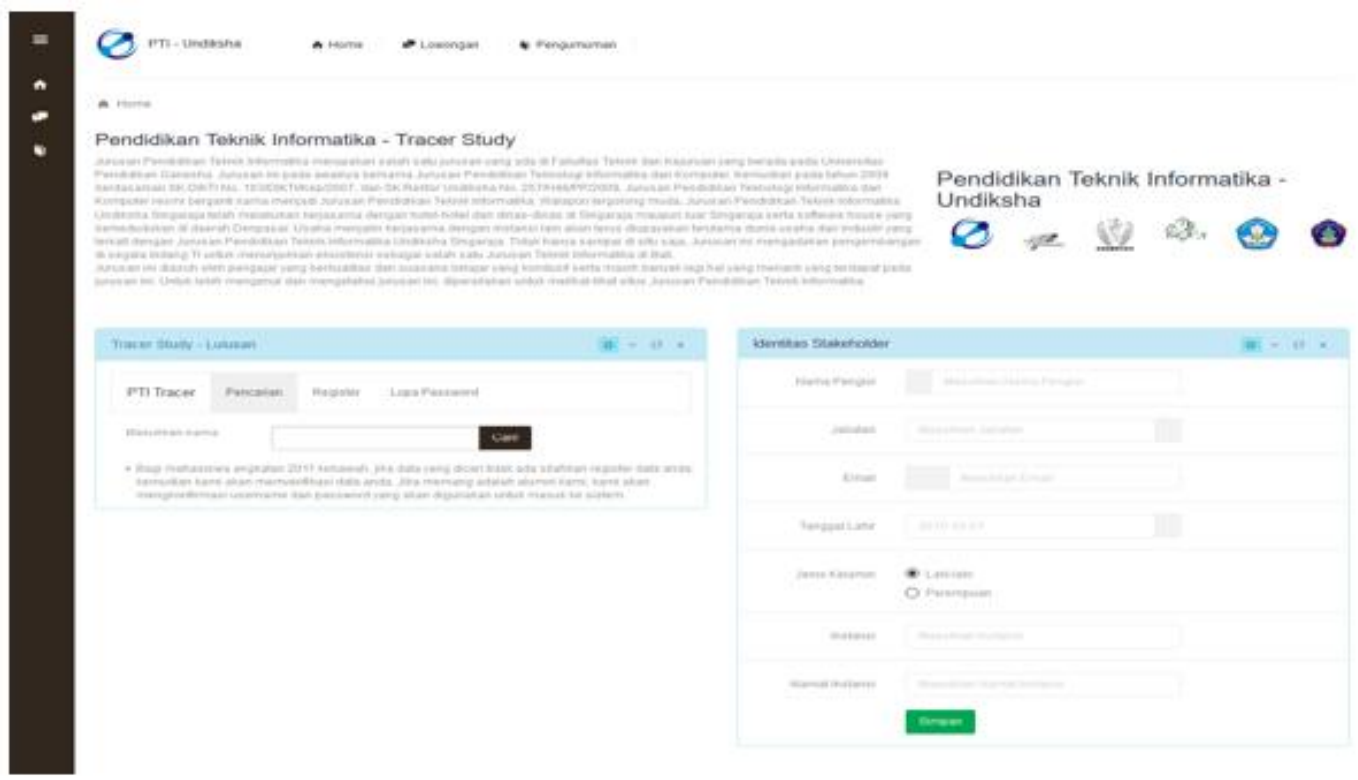

Gambar 8. Halaman depan Tracer Study

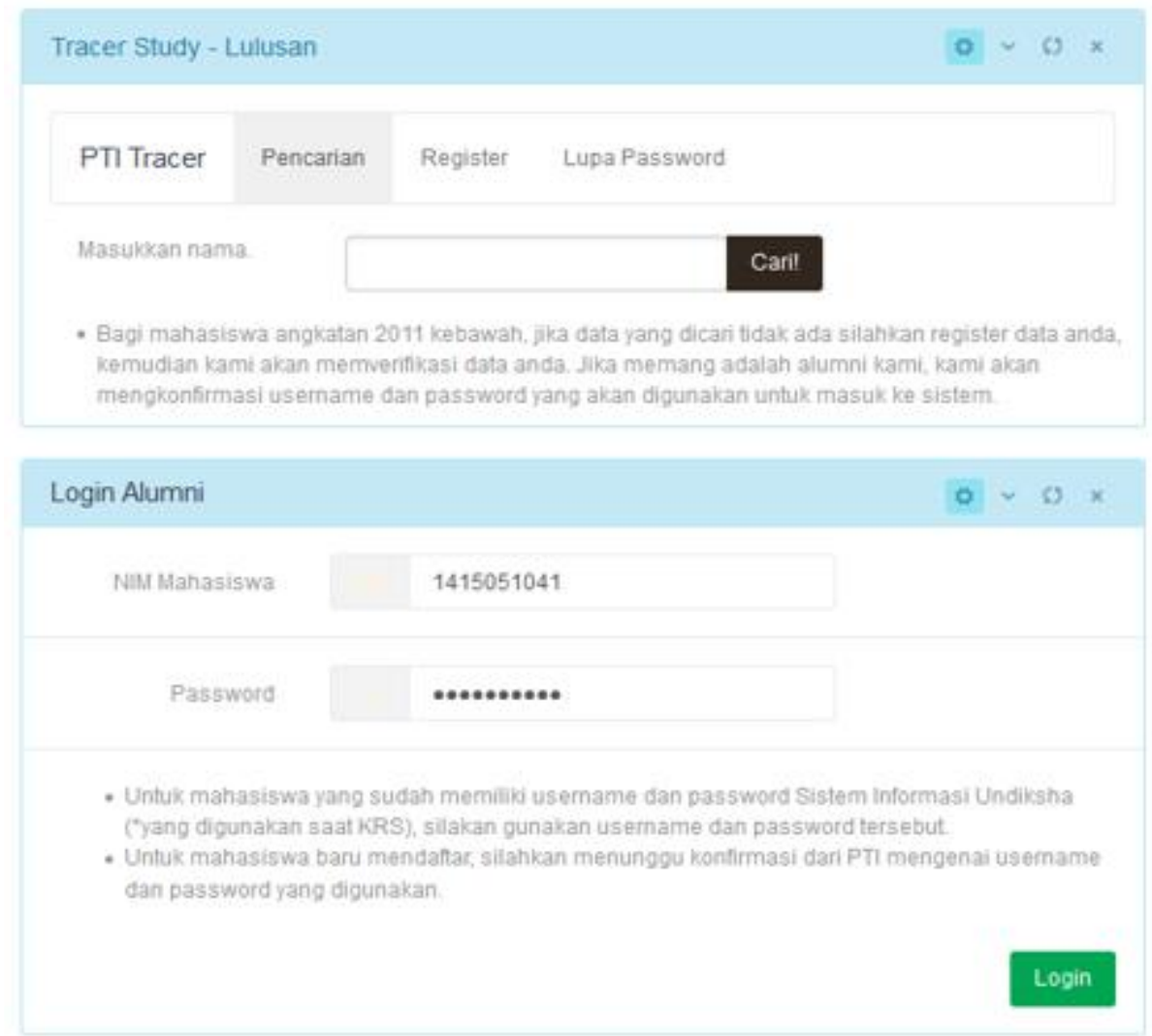

Gambar 9. Halaman Login 


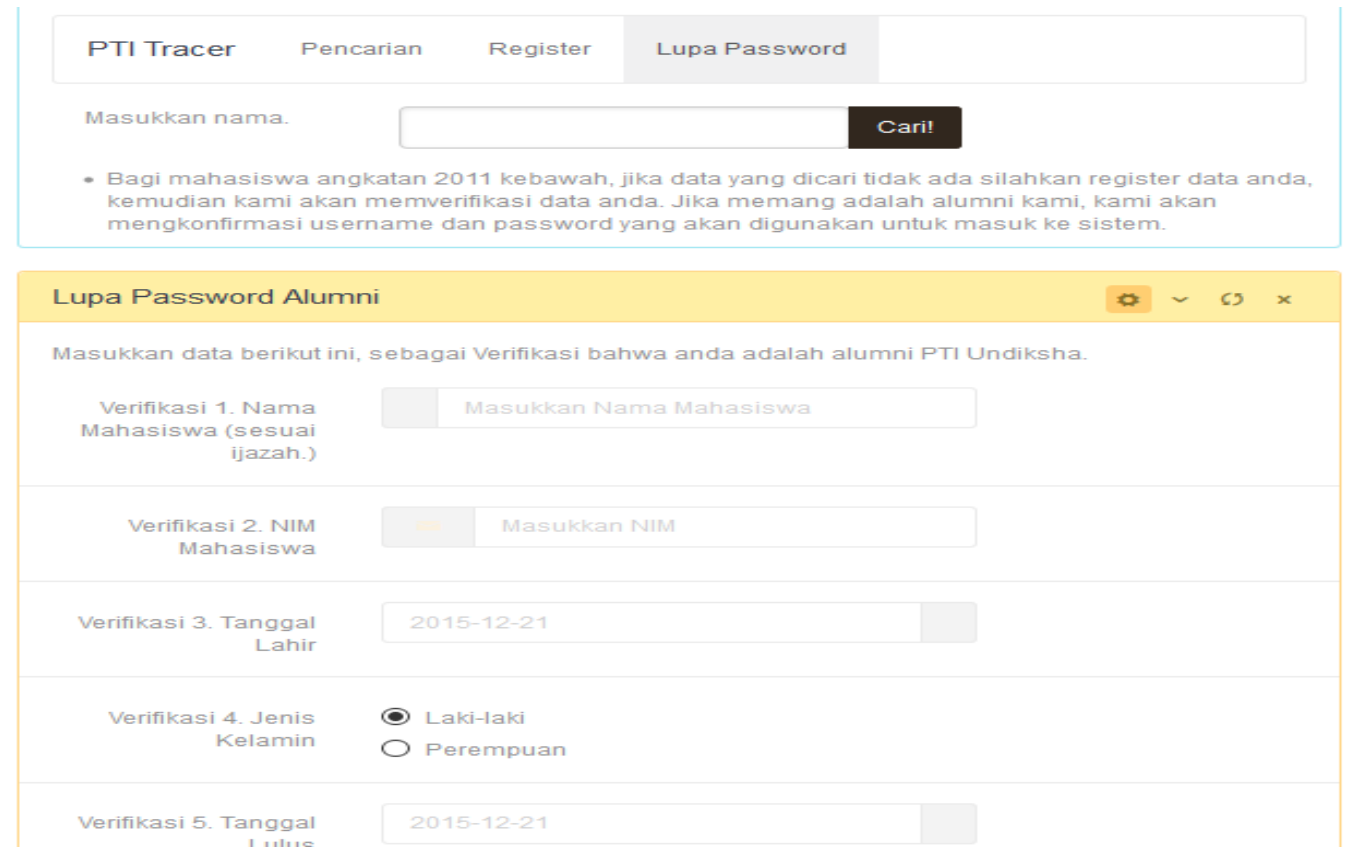

Gambar 10. Halaman Registrasi
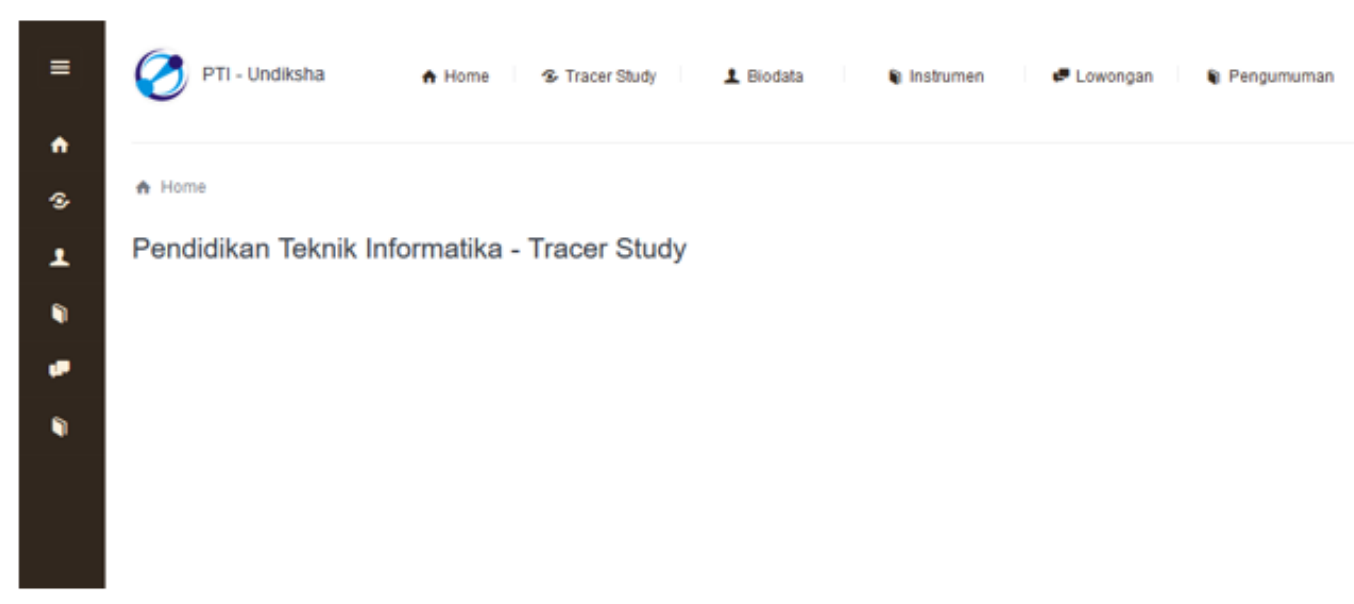

Gambar 11. Halaman Beranda

JPTK, UNDIKSHA, Vol. 13, No. 1, Januari 2016 : 35 - 49 


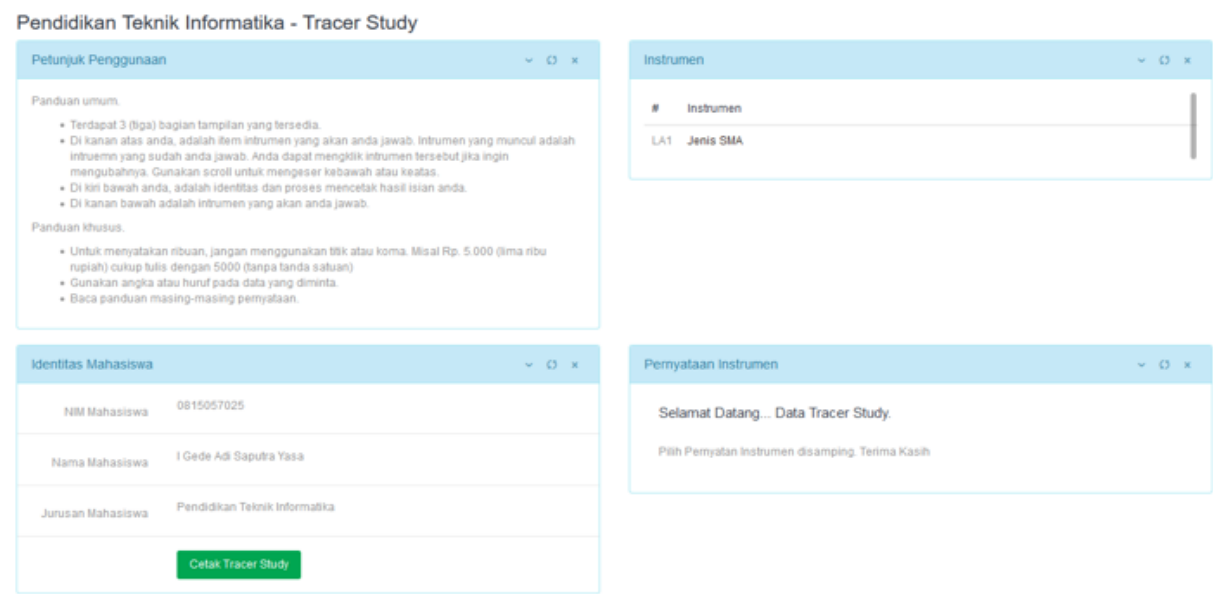

Gambar 12. Halaman Instrumen

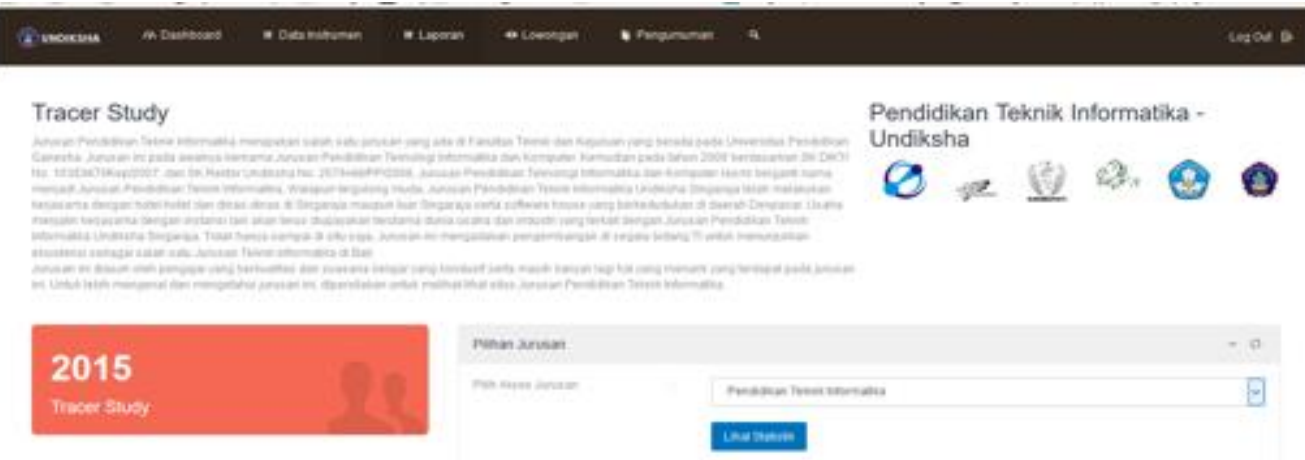

Gambar 13. Halaman Administrator

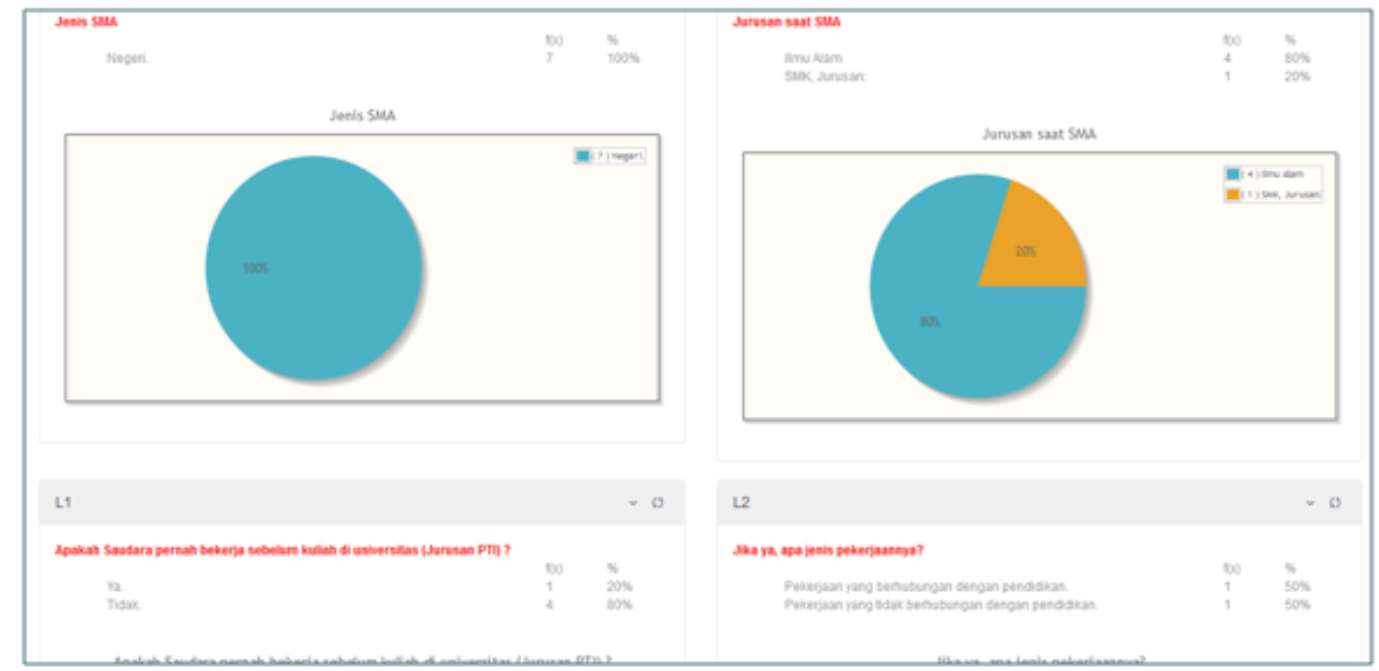

Gambar 14. Halaman Statistik Hasil Instrumen 


\section{Blackbox Testing}

Pada pengujian Blackbox, dilakukan dengan melakukan verifikasi terhadap kebutuhan fungsional sistem yang diharapkan saat perancangan diantaranya berupa kumpulan scenario yang diverifikasi sebagai berikut.

\begin{tabular}{|c|c|c|c|}
\hline Skenario & Langkah & $\begin{array}{l}\text { Hasil yang } \\
\text { diharapkan }\end{array}$ & Kesesuaian \\
\hline $\begin{array}{l}\text { Login ke } \\
\text { sistem Tracer } \\
\text { Study sebagai } \\
\text { lulusan }\end{array}$ & $\begin{array}{l}\text { 1. Masuk ke URL } \\
\text { http://pti.undiksha.ac.id/tr } \\
\underline{\text { acer }} \\
\text { 2. Masukkan nama pada tab } \\
\text { "Tracer-Study - Lulusan" } \\
\text { 3. Klik tombol "Cari!" }\end{array}$ & $\begin{array}{l}\text { Jika record } \\
\text { ditemukan, sistem } \\
\text { akan menampilkan } \\
\text { detil dari mahasiswa } \\
\text { dengan informasi } \\
\text { NIM, Nama, Jurusan, } \\
\text { Nama Ayah, Nama } \\
\text { Ibu, dan tombol } \\
\text { Login diperlihatkan. } \\
\text { Jika tidak ada record } \\
\text { yang sesuai, maka } \\
\text { sistem akan } \\
\text { menampilkan tabel } \\
\text { kosong }\end{array}$ & Sesuai \\
\hline $\begin{array}{l}\text { Mengisi tracer } \\
\text { Study sebagai } \\
\text { Stakeholder }\end{array}$ & $\begin{array}{l}\text { 1. Isi entry pada tab } \\
\text { "Identitas Stakeholder" } \\
\text { 2. Klik tombol "Simpan" }\end{array}$ & $\begin{array}{l}\text { Sistem menyimpan dan } \\
\text { dan menampilkan pesan } \\
\text { bahwa record telah } \\
\text { direkam ke database }\end{array}$ & Sesuai \\
\hline $\begin{array}{l}\text { Mengisi } \\
\text { Tracer Study } \\
\text { sebagai } \\
\text { lulusan }\end{array}$ & $\begin{array}{l}\text { 1. Login sebagai lulusan } \\
\text { 2. Klik menu "Instrumen } \rightarrow \\
\text { Input Instrumen" } \\
\text { 3. Isikan Survei }\end{array}$ & $\begin{array}{l}\text { System dapat } \\
\text { menyimpan hasil survei } \\
\text { dengan baik tanpa ada } \\
\text { error selama pengisian }\end{array}$ & Sesuai \\
\hline $\begin{array}{l}\text { Edit Biodata } \\
\text { Alumni }\end{array}$ & $\begin{array}{l}\text { 1. Login sebagai lulusan } \\
\text { 2. Klik menu "Biodata } \rightarrow \text { Edit } \\
\text { Biodata" } \\
\text { 3. Isikan detil yang bisa } \\
\text { diubah seperti Email, Jenis } \\
\text { kelamin, Status dan } \\
\text { Jurusan } \\
\text { 4. Klik "Simpan" }\end{array}$ & $\begin{array}{l}\text { System sukses dalam } \\
\text { menyimpan data } \\
\text { biodata tanpa ada } \text { error }\end{array}$ & Sesuai \\
\hline
\end{tabular}




\begin{tabular}{|c|c|c|c|}
\hline Skenario & Langkah & $\begin{array}{l}\text { Hasil yang } \\
\text { diharapkan }\end{array}$ & Kesesuaian \\
\hline $\begin{array}{l}\text { Fitur Lupa } \\
\text { Password }\end{array}$ & $\begin{array}{l}\text { 1. Masuk ke URL } \\
\underline{\text { http://pti.undiksha.ac.id/tra }} \\
\underline{\text { cer }} \\
\text { 2. Di bagian tab "Tracer } \\
\text { Study - Lulusan" Klik } \\
\text { menu "Lupa Password" } \\
\text { 3. Isikan entry Nama } \\
\text { Mahasiswa, NIM, Tanggal } \\
\text { Lahir, Jenis Kelamin, } \\
\text { Tanggal Lulus dan Email } \\
\text { 4. Klik tombol "Lupa } \\
\text { Password Alumni" }\end{array}$ & $\begin{array}{l}\text { System sukse dalam } \\
\text { me-reset password dan } \\
\text { password baru diterima } \\
\text { lewat email yang } \\
\text { didaftarkan }\end{array}$ & Sesuai \\
\hline
\end{tabular}

\section{Whitebox Testing}

Pada pengujian Whitebox, dilakukan verifikasi struktur dan algoritma pemrograman yang diantaranya mencakup scenario berikut ini.

\begin{tabular}{|c|c|c|c|}
\hline Skenario & $\begin{array}{l}\text { Algoritma/Struktur } \\
\text { Program }\end{array}$ & $\begin{array}{l}\text { Hasill yang } \\
\text { diharapkan }\end{array}$ & Kesesuaian \\
\hline $\begin{array}{lll}\text { Login } & \text { ke } & \text { sistem } \\
\text { Tracer Study } & \end{array}$ & 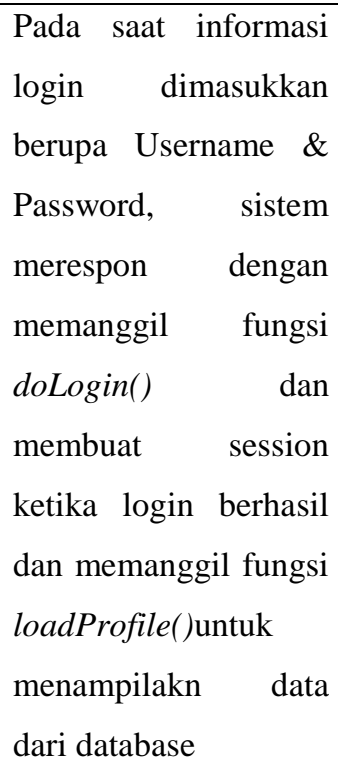 & $\begin{array}{lr}\text { Dua fungsi } & \text { tersebut } \\
\text { dipanggil } & \text { dan } \\
\text { informasi } & \text { mengenai } \\
\text { profil } & \text { alumni } \\
\text { ditampilkan } & \end{array}$ & Sesuai \\
\hline $\begin{array}{ll}\text { Register ke } & \text { sistem } \\
\text { Tracer Study } & \end{array}$ & $\begin{array}{l}\text { Pada saat fungsi } \\
\text { doFind() dipanggil } \\
\text { untuk menampilkan } \\
\text { data alumni yang }\end{array}$ & $\begin{array}{l}\text { Record baru dibuat di } \\
\text { database untuk profil } \\
\text { user yang dimasukkan }\end{array}$ & Sesuai \\
\hline
\end{tabular}




\begin{tabular}{|c|c|c|c|}
\hline Skenario & $\begin{array}{l}\text { Algoritma/Struktur } \\
\text { Program }\end{array}$ & $\begin{array}{l}\text { Hasill yang } \\
\text { diharapkan }\end{array}$ & Kesesuaian \\
\hline & 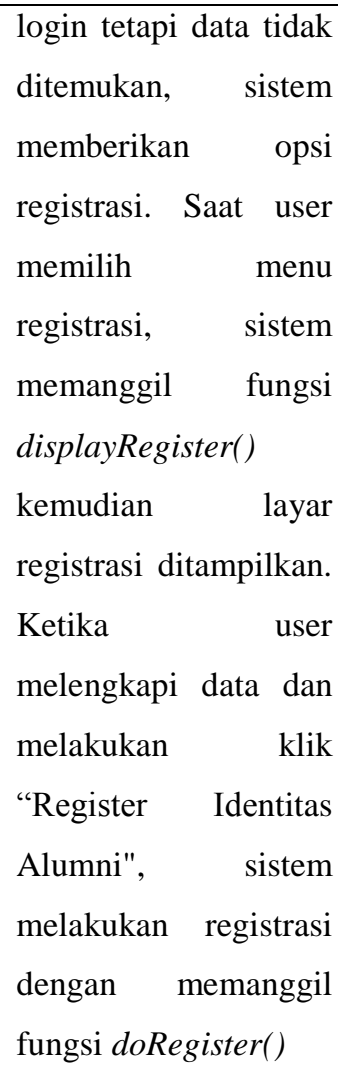 & & \\
\hline $\begin{array}{l}\text { Melihat data statistik } \\
\text { Tracer Study }\end{array}$ & 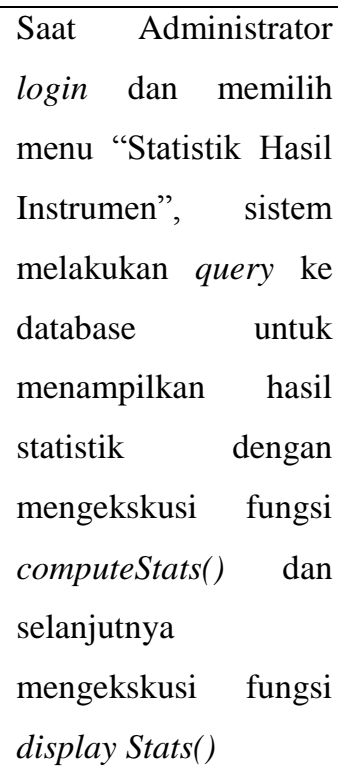 & $\begin{array}{l}\text { Sistem menampilkan } \\
\text { data statistik hasil } \\
\text { survei dengan } \\
\text { mengekskusi kedua } \\
\text { fungsi computeStats() } \\
\text { dan displayStats() }\end{array}$ & Sesuai \\
\hline
\end{tabular}

\section{PENUTUP}

Dari tahapan perancangan dan implementasi pengembangan website Alumni PTI Undiksha yang berupa penambahan fitur penting berupa Tracer Studyuntuk alumni telah melewati tahapan yang sesuai dengan standar pengembangan sistem client-server yang 
melalui tahapan pengembangan software dengan metodologi SDLC dengan model incremental yang secara ringkas melewati tahapan serupa dengan model waterfall yaitu, Analisis Kebutuhan, Desain dan Pembuatan, Testing dan dilanjutkan dengan tahapan Pemasangan atau deployment.

Dari hasil uji coba yang dilakukan, fitur aplikasi yang ditambahkan ke dalam Website PTI Undiksha yang memang sudah berjalan sebelumnya, sudah memenuhi fungsional aplikasi yang diharapkan sesuai rancangan.

Selama tahapan analisis kebutuhan dan perancangan tidak diketahui secara pasti sampai pada tahapan pengembangan yang dilakukan dalam penelitian ini bahwa telah ada sistem Tracer Study yang diperuntukkan bagi alumni mahasiswa Undiksha secara keseluruhan, sehingga fitur ini dirasa tumpang tindih terhadap website yang sudah ada. Ke depannya diharapkan agar website ini dikaji ulang untuk bisa diintegrasikan ataupun distandarkan sehingga tidak ada sistem-sitem yang tumpang tindih yang sebenarnya melakukan fungsi yang sama.

Adapun saran yang dapat diberikan terkait hasil implementasi sistem Tracer Study ini untuk dapat dikembangkan lebih lanjut, diantaranya (1) Ssistem yang dikembangkan belum menjangkau statistik terkait jumlah alumni dan stakeholders yang melakukan entry ke sistem (2) Sistem belum terintegrasi dengan Tracer Study yang digunakan oleh lembaga sehingga terjadi duplikasi informasi (3) perlu penambahan Statistik isian dari Stackholder (4) Sistem Tracer Study yang dikembangkan belum mengakomodasi kepentingan untuk mencetak statistik baik secara menyeluruh maupun per-bagian ke dalam format tertentu misalnya PDF, PNG, dll.

\section{DAFTAR PUSTAKA}

Lockhart Josh. 2015. Modern PHP: New Features and Good Practices. O'Reilly Media; 1st Edition.

Kelly Rainer R. and Prince Brad. 2013. Introduction to Information System. Wiley; 5th Edition

O'Brien, J A. 2003. Introduction to information systems: essentials for the e-business enterprise. Boston: McGraw-Hill

Susanto, Azhar. 2004. Sistem Informasi Manajemen Konsep dan Pengembangannya. Bandung: Lingga Jati.

Jogiyanto, HM. 2005. Analisis Dan Desain Sistem Informasi: Pendekatan Terstruktur. Edisi Kedua. Cetakan Pertama. PT Andi. Yogyakarta

Agarwal, B. B. et al. 2010. Software Engineering \& Testing. US. Jones and Bartlett Publishers, LLC 